\title{
Ynglingatal. Nya perspektiv på en kanske gammal text
}

\section{Av Hans Hägerdal}

\author{
Länk till presentation av Hans Hägerdal
}

I svensk historiografi finns det en kategori av material som numera sällan kommer till användning. Sedan ungefär ett halvsekel tillbaka har den fornvästnordiska litteraturen och den svenska akademiska historieskrivningen bjudit varandra farväl och gått skilda vägar efter ett intimt samröre på cirka tre sekler.[1]

Förvånande är detta inte. Det svenska historikerskrået har raskt travat fram i tiden och fattar numera vanligen posto någonstans på 1800- och 1900-talet där rikedomen på källmaterial förbjuder de fantasifulla utflykter som fornnordiska ämnen gärna för med sig. Historievetenskapen har sedan ungefärligen 1960-talet antagit utmaningen från samhällsvetenskaperna och sökt sig till nutidsrelevanta ämnen. Det finns också en metodisk sida av saken. De kraftfulla weibullianska källkritiska rallarsvingar som riktades mot sena, legendariska och obskyra pseudokällor till svensk historia har på det hela taget stått sig väl in i postmodern tid. Frågan är om inte de postmoderna tacklingarna har varit än tuffare. Positivistiskt anfäktade weibullianer ville finna de historiskt säkrade byggstenarna genom att rensa ut det fornnordiska skräpet, och bygga metodiskt säkra slutsatser utifrån detta. Idag går kritiken snarast ett steg längre med insikten om att även samtida eller nära samtida författare till en händelse är starkt styrda av sin kulturella hemvist.[2]

Material på poesi och prosa som nedtecknades på Island eller ibland Norge under hög- och senmedeltiden omtalar ganska ofta svenska förhållanden och borde rimligen kunna användas till någonting; frågan är bara till vad. Där de omtalar historiska förhållanden som ligger längre än något sekel tillbaka är de svåra att lägga till grund för en historisk rekonstruktion. Det är inte heller säkert att de kan användas för att belysa kulturella och geografiska förhållanden i Sverige i författarnas samtid eftersom det trots allt var en bra bit mellan Island och Sverige. Förvisso kan de fornvästnordiska texterna utnyttjas för att analysera omvärldens syn på medeltidssvenskarna, men det blir en ganska mager reträttpost.

Problemen blir än större då man betänker att framför allt det poetiska stoffet ofta är odaterbart. Eddadiktningen har åkt fram och tillbaka i tiden allteftersom de filologiska greppen och trenderna skiftat. För närvarande tycks den stora massan av eddadikter höra hemma i tiden efter kristnandet i Norden, vanligen på 1100- och 1200-talen. Dikter som Hávamál, Rigsthula och Bjarkamál placeras av försiktiga moderna filologer långt efter den vikingatid där de tidigare troddes höra hemma.

Det finns emellertid en kategori som fortfarande ses som användbar för äldre nordisk och i någon mån även svensk historia. Det gäller skaldediktningen. I de isländska sagorna, inte minst hos klassikern Snorre Sturlasson, citeras dessa skaldeverser flitigt och används ofta som en sorts stöd för det sagaskrivaren berättar: Titta här, redan samtida skalder upplyser oss om att det förhöll sig just så och så. Skaldedikterna är konstfärdigt hopsatta efter invecklade metriska regler och kan därför ofta "avslöjas" som sentida om de skulle vara illa traderade. De fungerar i de flesta fall som lovpris som diktas till ära för en hövding eller furste, och det framgår av dikterna att föremålet för prisandet förväntas ge en frikostig lön för diktarmödan. De skaldedikter som citeras i sagorna anknyts normalt till en viss skald och till en specifik historisk händelse som alltså i bästa fall kan dateras precis på året.

Exakt vad som är skaldeposesi är en smula oklart. Det kan enligt en definition ses som den 
poesi som skiljer sig från den eddiska och från rímur (rimmade berättelser). Vanligen innehåller skaldedikterna kenningar, det vill säga poetiska omskrivningar, vilket gör att de ofta blir så komplicerat sammansatta att, för att citera Frans G. Bengtssons Röde Orm, föga av dess innehåll kan förstås. [3] Så är till exempel "dalfiskens bädd" en omskrivning för guldet, eftersom dalfisken är den fjälliga varelse som slingrar omkring i dalen, i detta fall en drake, och drakar ruvar som bekant på guld. Längden på skaldedikterna varierar kraftigt, från enstaka bevarade strofer till omfångsrika alster med tjogtals strofer eller mer.

Enligt den vanligen etablerade kronologin härrör de äldsta skaldedikterna från kanske slutet av 800-talet. Relativt mycket stoff finns bevarat från den senare delen av vikingatiden, 900- och 1000-talen, och inte så lite från senare tid, 1100- och 1200-talen. Uppenbarligen förekom det under 1100-talet ett uppvaknat antikvariskt intresse där isländska skalder satte ihop långa dikter som Norges konungatal och Krakumál i gammal stil.

Till den äldre kategorin hör enligt den traditionella uppfattningen Ynglingatal, en dikt på versmåttet kviduháttr. Den består av 90 så kallade helmingar, det vill säga halvstrofer.[4] Det rör sig om en konstfärdig produkt, full av kenningar och mytiska anspelningar. Som upphovsman utpekas en Tjodolf av Hvin, en norsk poet som anges ha verkat på Harald Hårfagres tid, alltså i slutet av 800-talet eller början av 900-talet. Det som gör Ynglingatal till en mycket speciell text, vars innehåll diskuterats i det oändliga, är den centrala roll den har i norsk och i tidigare svensk historieskrivning. Dikten utgör en räcka av kungliga nekrologer - dödsnotiser - som i sitt bevarade skick spänner över tjugosju led. Vanligen uppfattas den som en genealogi så att vi får tjugosju generationer kungar vilka har svensk respektive norsk anknytning. De första tjugoen leden har uttalat svensk hemvist under det att de sista sex hör hemma i Vestfold i södra Norge. Den allra siste, Ragnvald Hederhög, är inte död än när dikten skrevs, och stroferna som lovsjunger honom ansluter sig till den gängse skaldiska panegyrik som vi har så många exempel på. Det är uttryckligen till Ragnvald diktaren riktar sitt verk, som alltså tycks avhandla furstens alla förfäder i tjugosex led.

Ynglingatal finns bevarad i 1200-talskrönikan Norges kungasagor eller Heimskringla som traditionellt tillskrivs Snorre Sturlasson - en uppgift som dock är sen, från ca 1600.[5] Dikten bildar stommen för Heimskringlas berättelser om Ynglingaätten som så småningom vandrade västerut till Vestfold och gav upphov till den medeltida norska kungaätten. Harald Hårfagre, den påstådde norske riksenaren, nämns inte i dikten, men enligt traditionen var han kusin till Ragnvald Hederhög.

Allt detta har inte onaturligt väckt svenska och norska historikers, filologers och arkeologers intresse. Versioner av ynglingagenealogin har varit kända i Sverige sedan åtminstone 1300-talet och inkorporerades i medeltida och senare svenska kungalistor. Detta så mycket mer som inhemska svenska traditioner inte går längre tillbaka än Erik Segersäll och Olof Skötkonung. Arkeologer som Birger Nerman och Sune Lindqvist och filologer som Elias Wessén och Adolf Noréen uppehöll sig med förkärlek vid Ynglingatal. Även en källkritiskt hårdkokt historiker som Curt Weibull använde dikten som vetenskapligt tillhygge i vissa av sina tidiga studier.[6]

Allt det här har naturligtvis bleknat i strålglans under det kritiska 1900-talet. I nyare svenska historieverk brukar Ynglingatals kungalista omnämnas kort med kommentaren att stoffet är alltför opålitligt för att kunna användas till särskilt mycket. Norrmännen har varit något mer ihärdiga i sitt intresse för Ynglingatal eftersom de sex sista leden i räckan tycks peka på hur ett vestfoldskt rike utvecklas i Sydnorge, som sedan expanderar till ett större norskt välde under Harald Hårfagre ca 900.

Det kan tyckas gott och väl, men även för skaldediktningens del har den moderna historiska och filologiska vetenskapen ibland sina dubier. Vad man vanligen tidigare har tagit för givet på ett slentrianmässigt sätt har varit att Ynglingatal verkligen är ett alster från sent 800-tal eller tidigt 900-tal. 
Egentligen har det inte alltid tagits för givet. Det pågick för något sekel sedan en ganska livlig debatt om vilken ålder man kunde tillmäta dikten, med betydande lärdomsgiganter som Sophus Bugge och Henrik Schück inblandade. Det fanns de som menade att dikten kunde vara något århundrade yngre än den vanligen tänktes vara, kanhända påverkad av keltiskt, irländskt kulturgods.[7]

Den här debatten lade sig så småningom. En svensk, Walter Åkerlund, utgav 1939 en mycket samvetsgrann studie över Ynglingatal där han menade att dikten faktiskt var gammal.[8] Det fanns inga övertygande belägg för ett senare datum, men däremot fanns filologiska skäl som pekade på en tidig datering - versfötterna gjorde intryck av att vara tidiga. Det fanns också ett tungt historiskt argument. Det är nämligen så att det existerar en dikt Háleygjatal som är fragmentariskt bevarad men som tycks ha varit en relativt andefattig efterbildning av Ynglingatal. Precis som Ynglingatal innehöll Háleygjatal (liksom senare Norges konungatal) från början tjugosju led (3 x $3 \times 3)$ och vissa formuleringar tycktes vara övertagna från Ynglingatal. Háleygjatal ska ha diktats till ära för Håkon Jarl, norsk härskare i slutet av 900-talet, för att ära hans förfäder, och Ynglingatal måste då vara äldre.

Den här uppfattningen kom att bli rådande.[9] Forskningen tenderade dessutom att tona ner frågeställningar rörande den äldsta medeltiden. Den gamla filologiska tradition som fanns på svensk mark började urholkas i andra hälften av 1900-talet, av orsaker vi inte närmare kan gå in på här. En av de fåtaliga akademiska forskare som tog upp Ynglingatal under denna tid var en tysk forskare, W. Baetke (Yngvi und die Ynglinger, Berlin 1964). Baetke använde sig av dikten för att komma åt den klassiska stridsfrågan om det sakrala kungadömet, alltså problemet huruvida kungen i det gamla fornnordiska samhället kunde betraktas som gudomlig. Baetke menade att så inte var fallet. Han visade att de dödsscener som spelades upp i Ynglingatal var rent jordiska trots de mytologiska hänvisningarna i dikten. Senare isländska traditioner ville visserligen låta ynglingarna härstamma från gudarna Njord och Frej, men deras vittnesbörd var sena och kunde förklaras som lärd konstruktion.

En något senare forskare, svensken Lars Lönnroth, förde i en artikel från 1986 fram åsikten att Ynglingatal inte ens var en lovdikt.[10] Han menade att flera av kungarna i räckan i själva verket dog en neslig, deklasserande död. En omkommer till följd av en dryck, en får en segelbom i skallen, en offras av sina egna undersåtar etc. Det var alltså något egenartat med diktens tillkomst - kanske hade den ett helt annat syfte än att lovprisa en furstes förfäder.

Så stod sakernas läge när 1990-talet gick in. Få personer försökte på ett vetenskapligt sätt göra något nytt av Ynglingatal som för övrigt var minerad mark. Frågan om diktens betydelse sågs antagligen som lite förlegad av historikerskrået och torde lätt ha renderat sina uttolkare en stämpel som oseriöst fantasifull. Stoff av detta slag lämnades åt amatörhistoriker och amatörarkeologer, exempelvis av Västgötaskolans märke.[11]

I den här situationen utkom 1991 en innehållsrik avhandling av norrmannen Claus Krag, Ynglingatal og Ynglingesaga: en studie i historiske kilder (Oslo 1991). Det var en bok som kom att väcka stor och berättigad uppmärksamhet. Claus Krag hade redan gjort sig känd som en ikonoklastisk historieforskare som gått hårt ut mot den hävdvunna uppfattningen att Norge från ca 900 skulle regerats av en sammanhängande Hårfagredynasti. Istället, menade Krag, rörde det sig om en succession av obesläktade hövdingafamiljer som tog makten och i senare historieskrivning inrangerades i en dynasti.

Med sin bok Ynglingatal og Ynglingesaga fortsatte han att provokativt utmana äldre historiska konventioner. Han menade att när man bedömde en text som Ynglingatal fick man ta hänsyn till den intellektuella miljö som fanns på Island på 1100-talet, strax innan Heimskringla skrevs. Gjorde man detta fick man förvisso en ny bild av Ynglingatal som historiskt dokument. Dikten var i högsta grad intressant, men inte som vittnesbörd om forntida svenska eller vestfoldska kungar utan som en högmedeltida genealogisk 
rekonstruktion från 1100-talet, innemot 1200. Därmed föll den norska uppfattningen om Norges tidiga vikingatid platt till marken. Kungarikets utsprung i Vestfold var inget annat än en sen konstruktion: historien fick skrivas om.

Hur kunde då Krag vara så säker på detta? Jo, han ansåg sig kunna visa på anakronismer i Ynglingatal som gjorde det omöjligt att dikten kunde vara från ca 900. Dessa anakronismer var av klassisk antik och kristen härkomst, saker som inte rimligen kunde vara kända för en hednisk vikingatida publik. En sådan anakronism var fyrelementsläran med rötter tillbaka till den grekisk-sicilianske filosofen Empedokles på 400-talet f.Kr. Tittar man på de fyra första leden i ynglingaräckan så dör var och en av furstarna en död förknippat med ett specifikt element. Den förste, Fjolner, dör av en dryck, den andre, Sveigder, trollas in i en sten, näste man, Vanlande, stryps av maran och dör alltså till följd av brist på luft, och Visbur bränns inne av sina egna söner. Sålunda är vatten, jord, luft och eld orsak till deras hädanfärd. Eftersom Krag tror att fyrelementsläran inte kan ha varit känd i det fornnordiska samhället så måste dikten vara ung.

I samma riktning pekar en tendens till historiserande av mytologiska element, euhemerism, som kan spåras i dikten. Detta betyder så mycket som att gudomligheter tänks ha varit verkliga människor en gång i tiden och efter sin död ha åtnjutit gudomlig dyrkan. Nu har just de fyra första namnen i ynglingräckan en gudomlig koppling. Fjolner, Sveigder och Visbur tycks vara omskrivningar av guden Oden, och Vanlande är ingen mindre än Frej. I anslutning till den tidigare Baetke kan då Krag hävda att även om dessa namn är mytiska så är händelserna rent jordiska, och detta ansluter till den euhemerism som vi finner på flera håll i tidigmedeltida kristen lärdom, men alltså inte i fornnordisk tradition.

För att ytterligare bestyrka sin omdatering går Krag igenom dikten i detalj och jämför den med Heimskringlas prosatext och med andra högmedeltida texter. Han finner då att det finns en nära överensstämmelse mellan dikten och Heimskringla, så att dikten inte alls tycks ha känts svårförståelig eller främmande för 1200-talsförfattaren till Heimskringla. Detta tyder förstås också på ett ungt datum.

Hur har då ynglingatraditionen uppstått? Enligt Krag är det mycket i sammanhanget som pekar tillbaka till Are Frode i början av 1100-talet - den lärdomsgigant som systematiserade så mycket historisk kunskap på Island. Han kompilerade uppenbarligen en ynglingagenealogi vilken kan ha varit hopplockad av legendariska namn som fåtts från flera olika håll - med verklig historia har dessa namn föga eller intet att skaffa. Denna räcka användes någon gång under 1100-talet eller framåt 1200 som underlag för dikten Ynglingatal.

Ammunition för denna hypotes finner Krag i det sätt på vilket vestfoldkungarna, de sex sista leden i kungaräckan, skildras. I sporadiska 1100-talskällor associeras dessa kungar egentligen inte med Vestfold utan snarare med Oplandene, ett annat norskt fylke. Det verkar alltså som om Vestfold kommer in först i sent 1100-tal, som en föreställd bas för Norges äldsta kungaätt. Anledningen till denna historiografiska-geografiska förändring är tydligen 1100-talets politiska konstellationer som gjorde det önskvärt att peka ut Vestfold som urcentrum.

Någon historisk räcka kungar av Oplandene är det dock inte fråga om. Personerna i Ynglingatal, Gudröd Vejdekonung, Olaf Geirstadalf och så vidare, har inlånats från annat håll. Gudröd är ingen mindre än den bekante danske kung Godfred (död 810), under det att Olaf kan likställas med en sjökung som etablerade sig på Irland under perioden 852-71.[12] Egentligen är det först med Harald Hårfagre som en historiker har tillräckligt med kött på benen för att dra välgrundade slutsatser om Norges historia.

Krags djärva tes väckte stor uppståndelse i forskarvärlden, och många tog upp den kastade handsken. På det hela taget kan man se en skillnad mellan filologer och historiker här. Filologer var tämligen skeptiska till Krags omdatering av Ynglingatal under det att flera historiker uttalade sig positivt - Peter Sawyer, Niels Lund med fler. Det man framför allt 
riktade in sig mot i sin kritik var att Krag måste pressa sitt stoff riktigt ordentligt för att få hypotesen att gå ihop. Varken fyrelementsläran eller euhemerismen var speciellt framträdande eller tydliga - Krags tolkning verkade helt enkelt krystad. Dessutom verkade det förvånande att sådan lärd bjässe som Heimskringlas författare inte insåg att den dikt han citerade var tillkommen i hans egen livstid snarare än tre sekler tidigare. Det finns en liknande dikt från 1100-talet kallad Norges konungatal, som är uppbyggd på samma sätt med tjugosju led. Att stilmässigt datera denna är inga större problem eftersom dikten skiljer sig ganska markant från de vikingatida skaldedikterna. Vi skulle alltså med Ynglingatal ha att göra med ett poetiskt alster som inte bara utgav sig för att vara gammalt utan också var förvillande arkaiskt i språk och stil - i så fall ett mästerligt utslag av 1100-talets antikvariska renässans.

Speciellt hade kritikerna svårt att acceptera Krags tolkning med tanke på de sista halvstroferna. Dessa behandlar faktiskt en småkung Ragnvald Hederhög till vars ära dikten är gjord. Om dikten varit en pastisch från 1100-talet, resonerade man, så borde väl sista strofen ha behandlat någon historiskt välkänd figur som Harald Hårfagre och inte den i övrigt okände Ragnvald Hederhög? Krag försökte komma undan problemet genom att påstå att diktaren hade tagit upp en äldre skaldedikt om Ragnvald och lagt denna dikt i slutet av sin nyskapelse, men det kändes mycket långsökt.

Jag kan tillägga att jag själv hade vissa historiskt betingade invändningar mot Krag i en recension för Historisk Tidskrift (1994:4). Till exempel nämner dikten ortnamnen Borre och Skiringsal i stroferna om Vestfoldkungarna. De var arkeologiskt viktiga platser under vikingatiden men omtalas inte så mycket senare. En annan invändning är: Var det verkligen så omöjligt att vissa kristna föreställningar var okända på skandinavisk botten före 1000talet?

Krag går inte närmare in på språkformerna i dikten; han är historiker snarare än filolog. Istället konstaterar han undanglidande att skaldediktningen är svår att datera utifrån språket. Just denna punkt har dock tagits upp av en senare forskare, Christopher D. Sapp.[13] Han har försökt bemöta Krag genom att göra en språklig jämförelse mellan Ynglingatal och andra skaldedikter på versmåttet kviduháttr. Han fäster sig i första hand vid den expletiva partikeln of som ibland används som ett förstärkningsord i äldre texter. Han studerar med vilken frekvens of förekommer i kviduháttr från äldsta tid till 1100-talet. Hans slutsats är att of i skaldiska sammanhang hade slutat vara språkligt produktivt på 1000-talet. Här verkar Ynglingatal passa in i den äldre perioden även om den passar in bättre på 900-talet än på 800-talet. Sapp tror inte heller att saken kunde bortförklaras genom att Ynglingatal skulle vara en pastisch som efterbildade äldre språkformer. De språkliga mönstren är alltför tydliga. En studie av olika slags versrader i kviduháttrdikterna ger nämligen liknande resultat: Sapp tycker sig kunna konstatera en utveckling där Ynglingatal hamnar i det äldre skiktet.

Mer intressant än detta är kanske att Krags forskningar har inspirerat till nya friska försök att utnyttja Ynglingatal som kulturhistorisk källtext. Inte mindre än tre nyutkomna avhandlingar har försökt att använda den omstridda dikten för att komma åt frågor kring det tidiga skandinaviska kungadömet. Mot all förmodan har verket tagits upp även av svensk akademisk forskning efter en lång lapsus.

Den första här är norskan Gro Steinsland som i sin fylliga bok Det hellige bryllup og norrøn kongeideologi (Oslo 1991) försöker använda Ynglingatal i kombination med vissa eddiska dikter för att finna mytiska föreställningar om kungadömets ursprung. Hon väljer att bortse från Krags omdatering och behandlar fortfarande Ynglingatal som en reminiscens av hedniska föreställningar. Hon fäster sig vid att den högmedeltida isländska traditionen gör den förste av Ynglingatals figurer, Fjolner, till son av guden Frej som i sin tur var gift med jättinnan Gerd. Med hänvisning till eddadikten Skirnismál frammanar Steinsland bilden av ett heligt bröllop, ett hieros gamos, mellan gud och jättinna, en förening av kosmiska krafter som frambringat den arketypiske urkungen, Fjolner. Detta bröllop kan då sägas symbolisera härskarens förening med det landområde han tillägnar sig. Detta ger 
också förklaringen på en företeelse som satt myror i huvudet på flera forskare. Ynglingakungarna dör ofta på ett våldsamt och bisarrt sätt: innebränd av sina söner, hängd i ett halssmycke, strypt av maran, offrad av sina undersåtar för god årsväxt och så vidare. Detta låter sig naturligt förklaras genom blandningen av guda- och jätteblod i kungaätten. Spänningen mellan de kosmiska krafterna leder till de jordiska härskarnas märkliga dödssätt.

Steinslands arbete har väckt stor uppmärksamhet och naturligtvis blandade reaktioner. Onekligen ger hennes tolkning en möjlig mening åt det legendariska stoffet. Men det finns flera aber. Fjolners härkomst från Frej och Gerd nämns ju inte i den bevarade dikten utan förekommer endast i högmedeltida traditioner från 1100- och 1200-talen. Därtill är Skirnismál och eventuellt Ynglingatal produkter som komponerats av kristna diktare, efter vikingatidens slut, och det är svårt att greppa hur mycket de egentligen kan ha vetat om det förkristna kungadömet.

En ytterligare författare som vågat sig in på den gäckande frågan om det tidiga kungadömet är Svante Norr som i sin avhandling To Rede and to Rown: Expressions of Early Scandinavian Kingship in Written Sources (Uppsala 1998) går en intressant balansgång mellan arkeologi, historia och filologi. Han förnekar inte att Krag kan ha rätt i ett och annat men hävdar att dikten gott och väl kan ha förändrats efter hand, och att det nuvarande resultatet är ett sammanflickat arbete med tillagda strofer av medeltida kristet märke.

Med utgångspunkt från detta känner han sig fri att dra slutsatser av de kungliga attribut som tilldelas successiva släktled i dikten. Han tror sig i den slutversion vi besitter finna en syn på kungadömets evolution, en utveckling mot kungaskapets perfektion. De första svenska kungagestalterna imiterar gudomliga handlingar. De följande figurerna tycks kännetecknas av successionsstrider och delat kungaskap. De därpå följande sveakungarna beskrivs som krigiska och deras krigiska aktiviteter sträcker sig ofta utanför det egna territoriet. De sista namnen, vestfoldkungarna, är förvisso krigiska men de beskyddar sitt land snarare än anfaller andra, och de definieras genom sin relation till undersåtarna. Norrs studie innehåller mycket annat dessutom: en ingående studie av bilden av Ingjald Illråde i olika traditionslager, en analys av Ansgarsvitans bild av det skandinaviska kungadömet, och en tolkning av den gäckande Sparlösastenen i Västergötland såsom ett dokument om övertagandet av en kungavärdighet. Metodiskt söker Norr göra komparationer mellan det nordiska materialet och den information vi har om de frankiska och anglosaxiska kungarikena. Detta ger en mycket klarare mening åt specifika uppgifter i Ynglingatal, i de äldsta runinskrifterna etc.

En av de senaste forskare som har utnyttjat Ynglingatals möjligheter som källtext är religionshistorikern Olof Sundqvist i boken Freyr's Offspring: Rulers and Religion in Ancient Svea Society (Uppsala 2002). Avhandlingen kännetecknas av en oerhörd lärdom, med en käll- och litteraturlista som omfattar nästan femtio tättryckta sidor. Han söker här pumpa det magra källmaterialet på det fornsvenska kungadömets natur, och vilka kontinuiteter som kan ha funnits mellan det hedniska och det medeltida kristna kungadömet. Framför allt är han intresserad av den gamla stridsfrågan om det sakrala kungadömet. Alltså, har kungen i det förkristna germanska-nordiska samhället tänkts som gudomlig eller härstammande från gudarna, och i besittning av speciella metafysiska, speciellt lycko- och årsväxtbringande krafter?

I motsats till Norr är han tvärt avvisande mot Krag. Han menar att Krags (och i förlängningen Norrs) dateringsargument är hårdragna och missvisande. I själva verket bygger han ganska mycket i sin analys just på Ynglingatal som han menar innehåller tydliga östnordiska (svenska) traditioner. Det gäller kenningar, ortnamn och personnamn i dikten. Tjodolf av Hvin tog alltså över en aktiv poetisk tradition från svenskt håll på 800talet då han skapade sin dikt. Sundqvist menar att passager i Ynglingatal återspeglar vissa kultiska funktioner och vissa företeelser som associerades med härskarna. Traditionerna kan i en del fall gå tillbaka till vendeltid eller till och med tidigare. Det gäller rollen som väktare av helgedomar, associationen med aristokratisk ryttarkultur, den tänkta gudomliga 
härkomsten, utövande av spådomskonst och en del ytterligare saker som antyds i stroferna. Tillsammans med ett brett men ganska bräckligt källmaterial från äldre medeltid kommer Sundqvist till slutsatsen att den klassiska akademiska föreställningen om ett sakralt kungadöme inte håller streck. Sveahärskare betraktades av allt att döma inte som gudomliga. Däremot hade de i teorin gudomlig härstamning och var starkt förbundna med rituella funktioner, med rituella fester som var del av ett forntida redistributionssystem.

Min egen uppfattning om Sundqvists bok är att den bygger på en mycket imponerande inläsning av stoff och sekundärlitteratur. Han underbygger sina argument så gott det låter sig göra med en oerhörd notapparat som inte kan väcka annat än beundran. Trots det vilar mycket av argumenteringen på lösan sand, därför att han måste försvara vissa obskyra källors ålder och trovärdighet för att få det hela att gå ihop. Trots hans starka invändningar mot Krag är dateringsfrågan av Ynglingatal på intet vis löst.

Kan man då alls dra någon rimlig slutsats av den ganska omfångsrika debatt om Ynglingatals användbarhet som historisk källa som rasat sedan tidigt 1990-tal? Just det faktum att debatten kommer upp nu är ganska intressant och kan förmodligen ses som ett indirekt uttryck för den lingvistiska omsvängning som varit rådande under senare decennier. Därmed menar jag att texter som vanligen använts på ett konventionellt historiskt manér har kommit att ses som texter i sig, som uttryck för sin tillkomstsituation, av upphovsmannens mentala horisonter. Sett på det viset kan vi, som Krag så riktigt säger, få en rikare bild av vad tidigmedeltida lärde uträttade, vilken miljö och vilka föreställningar de representerade. Man lämnar den gäckande fråga som ansatte gamla arkeologer som Nerman och Lindqvist, om hur mycket i den gamla källtexten som är historiskt sant, och studerar snarare det kultur- och mentalitetshistoriska värdet.

Dateringsfrågan är fortfarande viktig - det är ju en viss skillnad om vår dikt tillkommit 900 eller 1200 - men kan enligt min uppfattning inte lösas tillfredsställande med hittillsvarande metoder. Det måste förmodligen till en stor lingvistisk undersökning för att ge vidare ledtrådar - kanske de grepp som anvisats av Christopher Sapp kan utvecklas till en fastare argumentation. Samhället på 1100-talet var annorlunda än samhället på 900-talet, men likheterna är i alla fall tillräckligt stora för att vissa intressanta kulturhistoriska iakttagelser ska kunna göras. Dessa iakttagelser kan bland annat belysa drag i det äldre skandinaviska kungadömet, oavsett diktens exakta ålder.

\section{(C) Hans Hägerdal}

[1] Frågan om hur fornvästnordiskt material haft betydelse för svenska akademiska texter har senast behandlats av Anna Wallette, Sagans svenskar (Malmö 2004).

[2] För en dylik problematisering, se t ex Henrik Janson, Templum nobilissimum (Göteborg 1998). Janson bekänner sig emellertid inte uttryckligen till det postmoderna paradigmet.

[3] Frans G. Bengtsson, Röde Orm (Stockholm 1960), s. 120.

[4] Dikten har utgivits och översatts ett flertal gånger. Se t ex Snorre Sturluson, Nordiska kungasagor, del I., översatt av Karl G. Johansson (Stockholm 1991), s. 34-74.

[5] Karl G. Johansson, Oslo, muntlig kommunikation.

[6] Curt Weibull, 'Om det svenska och danska rikets uppkomst' i: Källkritik och historia. Norden under äldre medeltiden (Stockholm 1964). Essän utkom ursprungligen 1921.

[7] En diskussion om dessa frågor återfinns i Henrik Schück, 'De senaste undersökningarna rörande ynglingasagan' [Svensk] Historisk tidskrift 1895:1, s. 39-88. Schück ansåg dikten tillkommen något före 986 (a.a., s. 45).

[8] Walter Åkerlund, Studier över Ynglingatal (Lund 1939).

[9] En översiktlig sammanfattning av forskningsläget kring Ynglingatal återfinns i Hallvard Magerøy, 'Ynglingatal', i Kulturhistoriskt lexikon för nordisk medeltid 20 (Malmö 1976), s. 362-63.

[10] 'Dómaldi's Death and the Myth of Sacral Kingship', i J. Lindow et al. [ed.], Structure and Meaning in Old Norse Literature (Odense 1986).

[11] Henrik Janson har analyserat den så kallade västgötaskolans utveckling och 
Hans Hägerdal, 'Ynglingatal. Nya perspektiv på en kanske gammal text'

idéhistoriska sammanhang; Till frågan om Svearikets vagga (Vara 1999).

[12] Dessa identifikationer har gjorts långt tidigare, bland annat av Schück (a.a. 76-77), och har nu alltså åter kommit att framläggas. Diktens Gudröd dödades av en tjänare på order av Åsa, tydligen hans hustru, under det att Godfred enligt de frankiska riksannalerna mördades av en underlydande (a quodam satellite). Enligt den senare Gestis Karoli Magni, som dock är legendartad, mördades Godfred under en jakt av sin son som eggats av kungens försmådda hustru. Detta har tentativt sammankopplats med Gudröds tillnamn vejdekonung, "jaktkonung", som dock endast förekommer i prosatraditionen. [13] Christopher D. Sapp, 'Dating Ynglingatal. Chronological Metrical Developments in Kviduhattr', Skandinavistik 2002:2, s. 85-98 